\title{
Systemic versus local injection of bone marrow mesenchymal stem cells on 5-fluorouracil treated parotid glands of albino rats
}

Injeção sistêmica e local de células tronco da medula óssea em glandula parotida de ratos albinos tratados com 5-Fluorouracil

Caroline Maged MASSIEH $^{1}$ (D), Medhat Ahmed EL ZAINY² (D), Reham Magdy Mohammad AMIN ${ }^{2}$ (D), Iman Ahmed FATHY² (D)

1 - The British University in Egypt, Faculty of Dentistry, Oral Biology Department, Cairo, Egypt.

2 - Ain Shams University, Faculty of Dentistry, Oral Biology Department, Cairo, Egypt.

\begin{abstract}
Objective: Head and neck cancer is the sixth leading cancer by incidence worldwide and eighth by death. Recent reports revealed that, not only radiotherapy but also chemotherapy may induce xerostomia. The aim of this study was to compare the possible regenerative effect of BMSCs through systemic and local injections. Material and Methods: 52 male Albino rats were randomly divided into 4 groups: Group 1: 10 rats received $0.5 \mathrm{ml}$ of PBS by injection. Group 2: 14 rats received an intraperitoneal injection of 5-FU drug. Group 3: 14 rats were injected the same dose of 5-FU then received an intraglandular transplantation of BMSCs suspended in $0.5 \mathrm{ml}$ of PBS at day 1 after 5-FU administration. Group 4: 14 rats were injected the same dose of 5-FU then received an intravenous injection of BMSCs suspended in $0.5 \mathrm{ml}$ of PBS via the tail vein at day 1 after 5-FU administration. Results: Histological examination showed that group 2 showed features of severe degenerative changes which increased over time. Group 3 showed increasing amelioration in the ductal structure overtime. Group 4 also showed regenerated ductal elements however concerning apoptotic changes, immunohistochemistry results revealed improvement in both group 3 and 4 over group 2 with no statistical difference between groups 3 and 4. Conclusion: Histological and immunohistochemical features in group 3 and group 4 revealed similar amelioration in regenerative potentials. On the other hand, regenerative features of both experimental groups were statistically significant as compared independently to group 1.
\end{abstract}

\section{KEYWORDS}

5-fluourouracil; anti-caspase-3; BMSCs; H\&E; parotid salivary gland.

\section{RESUMO}

Objetivo: O carcinoma de cabeça e pescoço é o sexto câncer de maior incidência no mundo sendo a oitava causa de morte por cancer. Relatos recentes revelaram que não apenas a radioterapia, mas também a quimioterapia podem induzir xerostomia. O objetivo desse estudo foi comparar a possivel ação regenerative de BMSCs através de injeção local e sistêmica. Material e Métodos: 52 ratos Albino foram aleatoriamente alocados em 4 grupos: Grupo 1: 10 ratos que receberam $0.5 \mathrm{ml}$ de injeção de PBS. Grupo 2: 14 ratos que receberam injeção intraperitoneal da droga 5-FU. Grupo 3: 14 ratos que foram injetados com a mesma dose de 5-FU e receberam transplante intraglandular de BMSCs ressuspendidas em $0.5 \mathrm{~mL}$ de PBS no dia 1 após a administração do 5-FU. Grupo 4: 14 ratos que foram injetados com a mesma dose de 5-FU e receberam injeção intravenosa de BMSCs ressuspendidas em $0.5 \mathrm{~mL}$ de PBS via veia caudal 1 dia após a administração de 5-FU. Resultados: O exame histológico demonstrou que o grupo 2 apresentou alterações degenerativas severas que se agravaram com o tempo. O Grupo 3 mostrou melhora da estrutura ductal ao longo do experimento. Group 4 também mostrou elementos ductais regenerados. Referente a alterações apoptóticas, análise imunohistoquimica mostrou melhora nos grupos 3 e 4 comparados ao grupo 2, sendo que os grupos 3 e 4 foram estatisticamente semelhantes. Conclusão: Análises histológicas e imunohistoquímicas mostram que os grupos 3 e 4 apresentam melhora no potencial regenerativo. 
Por outro lado, os resultados observados para os dois grupos foi estatisticamente semlhante quando comparados independentemente ao grupo 1.

\section{PALAVRAS-CHAVE}

5-fluourouracil; anti-caspase-3; BMSCs; H\&E; glândula salivar parótida.

\section{INTRODUCTION}

Head and neck cancer is the sixth leading cancer by incidence worldwide and eighth by death [1]. Head and neck cancer therapy by radiation is known to result in significant oral side effects, such as significantly elevating the risk of xerostomia, candidiasis, dental decays, as well as oropharyngeal dysphagia. It is well established that xerostomia is manifested fundamentally by the impact of localized radiation over the major salivary glands (SGs). However, recent reports have revealed that chemotherapy may as well reduce the salivary flow and affect the saliva composition even when is not associated with radiotherapy [2].

5-Fluorouracil (5-FU) is in the antimetabolite and pyrimidine analog groups of chemotherapeutic agents [3]. It was patented in 1957, came into medical use in 1962, and is considered to be a pillar of chemotherapy regimens against a wide-broad spectrum of malignancies [4]. It can be applied as a cream to treat basal cell carcinoma, actinic keratosis and skin warts [5]. As intravenous (IV) injection, it is used to treat colon cancer, hepatic cancer, esophageal cancer, stomach cancer, pancreatic cancer and breast cancer. However, it has many adverse effects on multiple organs including the SGs [6].

Stem cell therapy is a trending and rising treatment modality of various diseases. Bone marrow is known to be a reliable and functional environment that comprises stem cells, such as adult mesenchymal stem cells (MSCs) that can regenerate, proliferate and differentiate into various cell types [7]. It is clearly demonstrated that bone marrow mesenchymal stem cells (BMSCs) retains a high differentiation potential to a broad range of cells in vitro and thus play an important role in fields of regenerative medicine and dentistry [8].

However, almost all studies regarding BMSC therapy for SGs were only concerned with the damaging effects of radiation therapy on the submandibular glands (SMGs) solely [9] while relatively few studies investigated chemotherapyinduced SG injury.

So, this work was conducted to compare the possible regenerative effect of two routes of BMSCs administration (systemic injection and local transplantation) on the parotid glands, histologically and immunohistologically. It was also aimed to evaluate the effect of chemotherapeutic agents - 5-FU - on the parotid glands (PGs) of albino rats.

\section{MATERIALS AND METHODS}

\section{Materials}

5-FU was purchased from Hikma specialized Pharmaceuticals (Utoral), Cairo, Egypt, as ampoules $250 \mathrm{mg} / 5 \mathrm{ml}$. The BMSCs were purchased from the Stem Cell Unit at the Histology Department, Faculty of Medicine, Ain Shams University, Cairo, Egypt. Cells were isolated from femur bones of albino rats as described by Sumita et al. [10]. Cells were used for the experiment after the third passage. BMSCs features were demonstrated by typical spindle-shaped morphology and adherence to plastic walls. Cells were also characterized by flow cytometry analysis as described by Lotfy et al. [11]. BMSCs were negative for the hematopoietic lineage marker CD45 and positive for CD29 and CD90. Also, Caspase 3 primary polyclonal antibody (ThermoFisher Scientific Catalog \# MA1-91637, USA) was used for detection of apoptotic cells.

\section{Experimental design}

The animals were housed in a sterile, controlled environment $\left(24 \pm 2{ }^{\circ} \mathrm{C}\right.$ and $12 \mathrm{~h}$ dark/light cycles) and fed with standard pellets diet and tap water. They were divided and kept in individual cages, nine rats per cage. The experiment was conducted according to the guidelines of animal experimentation and approved by institution guide lines of Ain Shams 
University Ethical Committee with authorization number (FDASU -Rec IM031905).

Fifty two male Albino rats of 200 250 g weight (5 6 months of age) were used in this study. The rats were obtained from the Animal House of Ain Shams University, Cairo, Egypt, and were divided into 4 groups, each group was further subdivided into 2 subgroups according to the day of euthanization:

Group 1 (PBS group): Ten rats received $0.5 \mathrm{ml}$ of PBS by injection and were considered as negative control;

Group 2 (5-FU group): 14 rats received a single intraperitoneal (IP) injection of Fluorouracil drug $(20 \mathrm{mg} / \mathrm{kg})$ each and were considered as positive control [12];

Group 3 (Local transplantation group): 14 rats were injected the same dose of 5 -FU then received local intraglandular (IG) transplantation of BMSCs $\left(5 \times 10^{5}\right.$ cells $)$ suspended in $0.5 \mathrm{ml}$ of PBS at day 1 after 5-FU administration [13];

Group 4 (Systemic administration group): 14 rats were injected the same dose of 5 -FU then received an intravenous (IV) injection of BMSCs $\left(2 \times 10^{6}\right.$ cells) suspended in $0.5 \mathrm{ml}$ of PBS via the tail vein at day 1 after 5 -FU administration [14].
Five rats of group (1) and seven rats of each of the three groups (2, 3 and 4$)$ were sacrificed at days 6 and 10 after 5-FU or PBS administration, as represented in Figure 1.

\section{Sample preparation for light microscopy}

Specimens of the PGs were prepared for examination under the light microscope. PGs were excised and fixed immediately in $10 \%$ neural buffered formalin solution for 48 hours. The specimens were then processed and embedded in paraffin wax according to standard technique. Two sets of serial 4-5 $\mu \mathrm{m}$ thickness sections were obtained and mounted on clean glass slides. One set was prepared for hematoxylin and eosin (H\&E) staining [15], the other set was prepared for Caspase- 3 immunohistochemical staining [16]. Rat spleen was used as a positive and negative control. The positive control reaction was detected as brown color; the cellular localization of this antibody is nuclear and cytoplasmic. The negative control reaction was detected as blue color.

\section{Morphometric assessment of present acinar tissue}

For each group, five H\&E-stained photomicrographs were captured at original magnification of X40. All images were captured

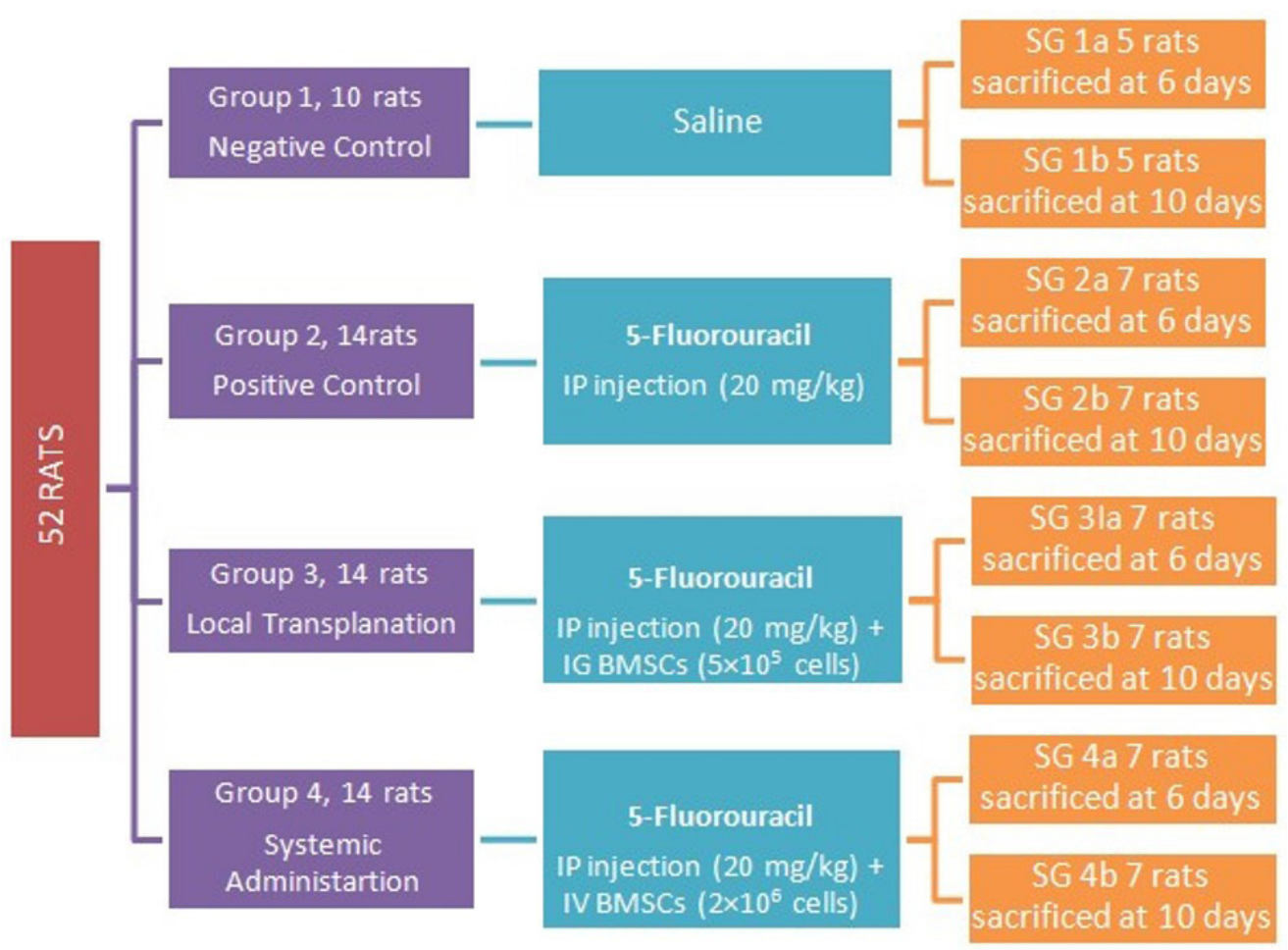

Figure 1 - Diagram representing grouping of animals. 
using digital camera (EOS206, Canon, Japan) which was mounted on a light microscope (BX60, Olympus, Japan). Images were then transferred to the computer system for analysis.

All the steps of analysis were carried out using Image J, 1.41a, (NIH, USA) image analysis software. Images were first corrected for brightness and contrast. Any ductal or stromal elements present were removed. Images, with only acinar tissue then, were converted into 8-bit grayscale type. Color thresholding was accomplished. The area fraction (AF) of acini was measured automatically. The area fraction represents the percentage of the acinar tissue to the total area of the microscopic field. The mean area fraction (MAF) for each case was calculated and the collected data were tabulated in Microsoft Excel sheet to be further statistically analyzed.

\section{Immunohistochemical assessment of cas- pase-3 expression}

For each group, five photomicrographs showing evident caspase- 3 immunopositivity were selected. The photomicrographs were captured at original magnification of X40. The digital images were obtained the same way as those of the H\&E-stained ones.

All the steps of immunohistochemical assessment were carried out, also, using Image $\mathrm{J}$ image analysis software. For evaluation of Caspase-3 immunoreactivity, only acinar and ductal cells displaying nuclear/cytoplasmic/membranous staining were regarded immunopositive. So, any stromal cells or intraluminal secretions with brown immunostaining were excluded. Images were first corrected for brightness and contrast. Corrected images were then converted into 8-bit grayscale type. Color thresholding was adjusted to only extract the immunoreactive cells. In photomicrographs, where positive immunoreactions were present, the area fraction of immunopositivity was measured automatically. The area fraction represents the percentage of Caspase-3-immunopositive cells to the total area of the microscopic field. MAF for each case was calculated. The collected data were tabulated in Microsoft Excel sheet to be subsequently analyzed statistically.

\section{Statistical analysis}

Statistical analysis was performed using IBM SPSS software for Windows (Version 20). Data was presented as mean and standard deviation (SD). The significance level was set at $\mathrm{P} \leq 0.05$. Kolmogorov-Smirnov and Shapiro-Wilk tests were used to assess data normality. All intergroup comparisons of acinar area fraction percentage at each time period were performed by One-Way ANOVA. Intragroup comparisons of acinar area fraction percentage between both time periods were conducted using Independent Student t-test. One-way ANOVA test was used to compare between groups regarding surface area positive reaction to Anti-Caspase-3 followed by Tukey post hock test.

\section{RESULTS}

\section{Hematoxylin and eosin results}

In the current study, regarding the results of Group 1 (negative control), examination of the H\&E stained sections revealed PG with normal histological architecture. The gland was encapsulated by a fibrous connective tissue capsule that sent out septa which divided the gland into lobes and smaller lobules, which were surrounded by normal vasculature. The gland showed a normal histological picture for serous acini, intercalated ducts (IDs) and striated ducts (SDs) (Figure 2A). The excretory ducts (EDs) were detected in the connective tissue (CT) septa between the lobes. They were lined by pseudostratified columnar epithelium and showed an empty lumen (Figure 3A).

Regarding rats sacrificed of Group 2, histological results at day 6 showed spacing between the acini and surrounding the ducts. Serous acinar cells showed ill-defined cell outline, faint basophilic cytoplasm with multiple different sized vacuolations. The nuclei appeared hyperchromatic, some appeared crescent-shaped and others bi-nucleated. The IDs showed regular outline with cytoplasmic vacuolations and centrally situated nuclei. The SDs cells appeared with ill-defined outline. The lining cells also appeared reduced in height with multiple cytoplasmic vacuolations and the lumen appeared dilated. In other specimens, the SDs lining cells appeared degenerated. Dilation of neighboring BVs and massive extravasation of red blood cells (RBCs) with presence of inflammatory cells were also detected (Figure 2B).

Regarding rats sacrificed of Group 2, histological results at day 10 showed serous acini 

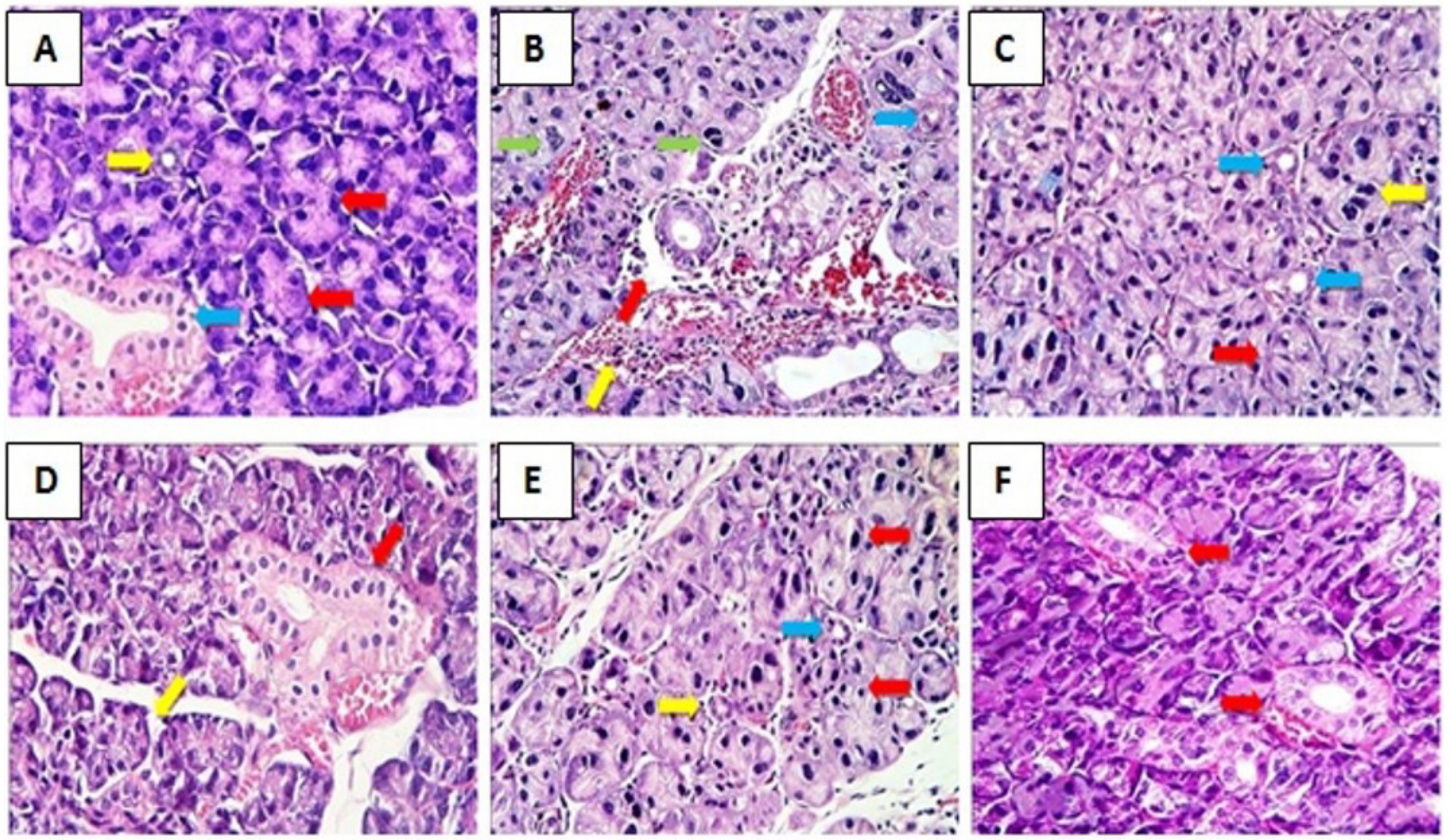

Figure 2 - Photomicrographs of rat parotid salivary gland of (A). Group 1 showing: serous acini (red arrow). The ID appear with cuboidal cell lining (yellow arrow). The SD appear lined by columnar cells with basal striations (blue arrow); (B) Group 2 at day 6 showing: III-defined cell outline of the serous acini with faint basophilic cytoplasm with multiple vacuolations and pleomorphic nuclei (green arrows). ID lining cells appear reduced in height and their nuclei appear pale and vesicular with some cytoplasmic vacuolations (blue arrow). SDs with multiple cytoplasmic vacuoles, loss of basal striation and areas of destruction (red arrow). Massive extravasation of RBCs can also be detected (yellow arrow); (C) Group 3 at day 6 showing: serous acini with a definite outline. Lining cells appear basophilic with some cytoplasmic vacuolations. Most of the nuclei appear hyperchromatic (yellow arrow). IDs with lining cells reduced in height and dilated lumens are also detected (blue arrows); (D) Group 3 at day 10 showing: SDs with some lining cells appearing ill-defined and others maintaining basal striation (red arrow). Slight widening in between the lobules and acini is seen (yellow arrow). Neighboring BVs appear dilated; (E) Group 4 at day 6 showing: serous acini with basophilic cytoplasm and the nuclei (red arrow). Minimal cytoplasmic vacuolations are also seen. IDs with an ill-defined cell outline and lumen appear surrounded with spacing (yellow arrow) while other ducts appear lined by cuboidal cells (blue arrow); (F) Group 4 at day 10 showing: SDs retaining almost normal appearance with columnar lining cells, basal striation and rounded nuclei (red arrows) (H\&E, orig. mag. X400).

and their lining cells appeared with an ill-defined cell outline and faint basophilic cytoplasm with multiple different-sized vacuolations. Some of the acinar cell nuclei appeared large, irregular and hyperchromatic. Other acinar cell nuclei represented morphological signs of apoptosis. Some nuclei appeared crescent in shape, others appeared ring-like and others appeared vesicular. Extravasated RBCs could be obviously detected between the acini. Most of the ED lining cells showed loss of pseudo-stratification, others showed signs of degeneration and vacuolations. The duct lumen showed desquamated cells. The CT surrounding the duct showed areas of degeneration and the neighboring blood vessels (BVs) were dilated and showed inflammatory cells in their lumen (Figure 3B).

Regarding histological results of Group 3 of rats sacrificed at day 6 showed the serous acini with a definite outline. The lining acinar cells appeared basophilic with minimal cytoplasmic vacuolations. Most of the nuclei appeared hyperchromatic. The IDs were detected with lining cells reduced in height and dilated lumens (Figures 2C and 3C). The EDs lining cells appeared with ill-defined cell outline. Some lining cells showed cytoplasmic vacuolations while others showed signs of degeneration. The lumen of the ducts showed pink stained stagnated secretion. The ducts were surrounded with fibrous CT with minimal areas of degeneration. The neighboring BVs appeared dilated. Few lymphocytic infiltrations were also observed (Figure 3C).

Regarding histological results of Group 3 of rats sacrificed at day 10 showed the serous acini with a definite outline. The lining acinar cells appeared basophilic with minimal cytoplasmic vacuolations. Some nuclei appeared hyperchromatic. The SDs lining cells appeared with loss of basal 

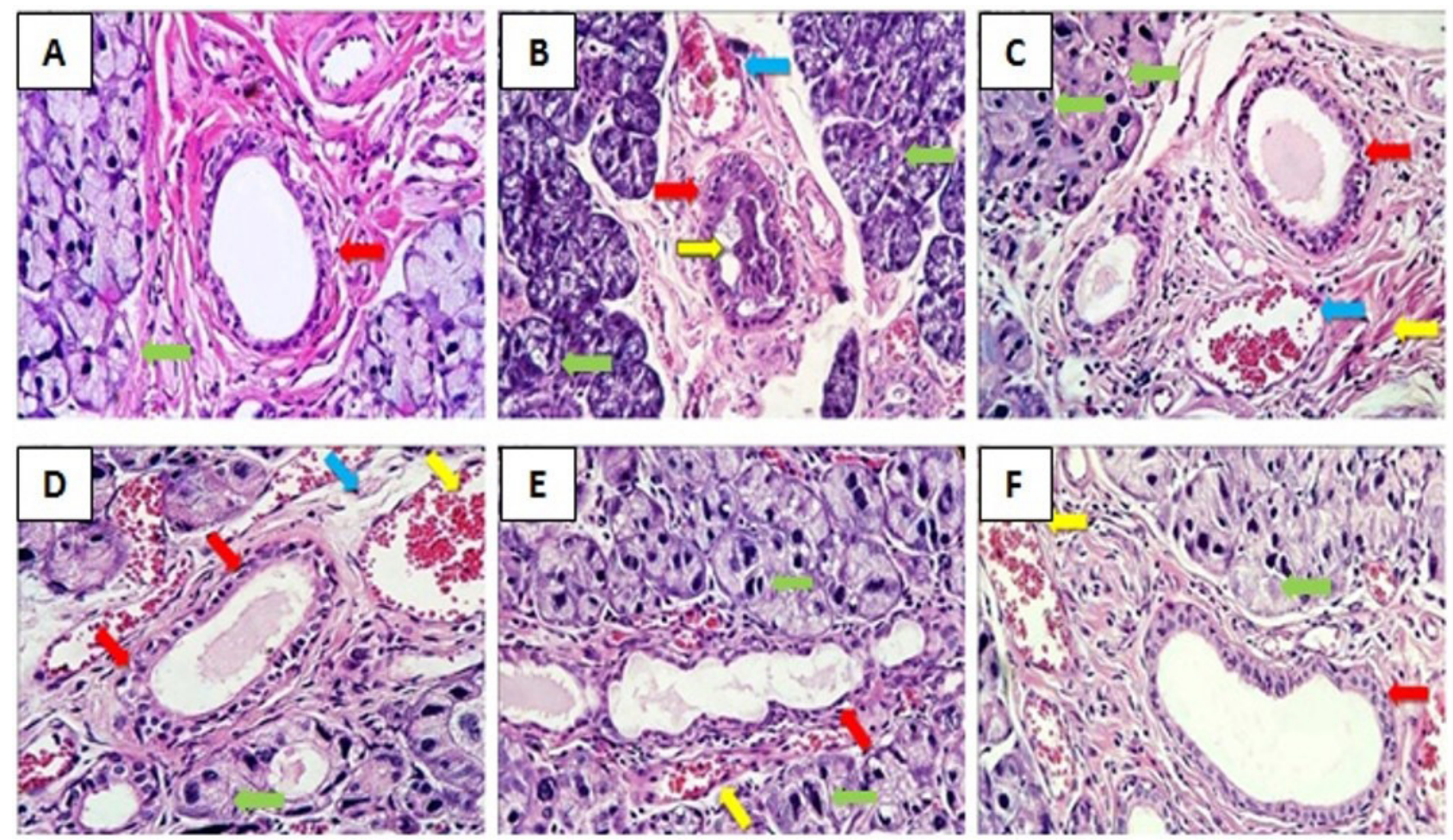

Figure 3 - Photomicrographs of rat parotid salivary gland of (A) Group 1 showing: serous acini (green arrow). The EDs lined by pseudostratified columnar epithelium and showing an empty lumen (red arrow); (B) Group 2 at day 10 showing: serous acini and their lining cells with illdefined outline, pale basophilic cytoplasm and different-sized vacuolations (green arrows). ED with loss of pseudo-stratification and signs of degeneration and vacuolations in the lining cells can also be detected (red arrow). The duct lumen showing desquamated cells (yellow arrow). The CT surrounding the duct showing areas of degeneration and the neighboring BVs are dilated with engorged RBCs and inflammatory cells in their lumen (blue arrow); (C) Group 3 at day 6 showing: serous acini with a definite outline. Lining cells appear basophilically stained with some cytoplasmic vacuolations. Most of the nuclei appear hyperchromatic (green arrows). EDs show signs of degeneration with pink stained stagnated secretion in the lumen (red arrow). The ducts appear surrounded with fibrous CT with minimal areas of degeneration (yellow arrow). The neighboring BVs appeared dilated. Few lymphocytic infiltrations were also observed; (D) Group 3 at day 10 showing: Showing serous acini with a definite outline. The lining acinar cells appearing basophilic with minimal cytoplasmic vacuolations (green arrow). The ED appear with ill-defined cell outline, with reduced height and loss of pseudo-stratification. Some cytoplasmic vacuolations are also detected (red arrows). The lumen of the ducts showed homogenous pink stained stagnated secretion. The neighboring BVs appear dilate with few lymphocytic infiltrations observed (yellow arrow). The surrounding fibrous CT show areas of slight degeneration (blue arrow); (E) Group 4 at day 6 showing: serous acini with basophilic cytoplasm and hyperchromatic and pleomorphic nuclei (green arrow). Some cytoplasmic vacuolations are also seen. EDs lined by pseudostratified columnar epithelium with small area of degenerative cells and cytoplasmic vacuoles (red arrow). Stagnant secretion is seen in the lumen. Congested BVs engorged with RBCs and some lymphocytic infiltrations are also observed (yellow arrow); (F) Group 4 at day 10 showing: serous acini with basophilic cytoplasm and minimal hyperchromatic nuclei. Minimal cytoplasmic vacuolations could be detected (green arrow). ED lined by pseudostratified columnar epithelium and minimal cytoplasmic vacuoles (red arrow). Congested BVs engorged with RBCs surrounded by fibrous CT are also detected (yellow arrow) (H\&E, orig. mag. X400)

striations and reduction in height, while other cells maintained their basal striation. Slight widening in between the lobules and acini were detected. Neighboring BVs appeared dilated with engorged RBCs in their lumen (Figures 2D and 3D). The EDs lining cells appeared with ill-defined cell outline. Some lining cells were reduced height with loss of pseudo-stratification. Some cytoplasmic vacuolations were detected. The lumen of the ducts showed homogenous pink stained stagnated secretion. The neighboring BVs appeared dilated. Few lymphocytic infiltrations were also observed. The surrounding fibrous CT showed areas of slight degeneration (Figure 3D).

Regarding histological results of Group 4 of rats sacrificed at day 6 showed the serous acini with basophilic cytoplasm and nuclei appeared hyperchromatic and pleomorphic. Minimal cytoplasmic vacuolations were detected. Some IDs appeared surrounded with spacing with illdefined cell outline and lumen while other ducts were lined by cuboidal cells (Figures $2 \mathrm{E}$ and $3 \mathrm{E}$ ). The EDs were lined by pseudostratified columnar epithelium with small area of degenerative cells and cytoplasmic vacuoles. Stagnant secretions were detected in the lumen. Congested BVs engorged with RBCs and some lymphocytic infiltrations were also detected (Figure 3E).

Regarding histological results of Group 4 of rats sacrificed at day 10 showed the serous acini with basophilic cytoplasm and nuclei appeared hyperchromatic and pleomorphic. Minimal cytoplasmic vacuolations were detected. The SDs appeared lined by columnar cells and 
maintained basal striation. Minimal cytoplasmic vacuolations could be detected. Some dilation of the surrounding BVs was also detected (Figures 2F and 3F). The EDs were lined by pseudostratified columnar epithelium and minimal cytoplasmic vacuoles. Congested BVs engorged with RBCs surrounded by fibrous CT were also detected (Figure 3F).

\section{Immunohistochemical results}

Immunohistochemical staining of PG sections of Group 1 showed minimal observed positive reaction (Figures 4A and 5A), while according to image analysis results, both acinar and ductal cells showed positive stained reaction to anticaspase-3 in other groups with variant degrees. Wide areas reacted positively at day 10 in groups 2, 3 and 4 (Figures 4D, 4F, 5B, 5D and 5F) and less wide areas were detected at day 6 (Figures 4B, 4C, 4E, 5C and 5E).

\section{Statistical analysis}

\section{Acinar area fraction}

One Way ANOVA (Table I) showed that there was a statistically significant difference in mean acinar area fraction between study groups after 6 days $(\mathrm{P}=0.004)$ and 10 days $(\mathrm{P}=0.005)$. Group 1 (negative control) and group 4 (systemic administration group) displayed the significantly higher mean acinar area fraction compared to group 2 (positive control) $(\mathrm{P}<0.05)$. While group 3 (local transplantation group) did not differ significantly from that of groups 1,2 and $4(\mathrm{P}>0.05)$.

Independent Student t-test (Table I) showed that there was no statistically significant difference in mean acinar area fraction between both time periods within each study group $(\mathrm{P}=0.547$ in group $1, \mathrm{P}=0.556$ in group $2, \mathrm{P}=0.616$ in group 3 and $\mathrm{P}=0.280$ in group 4 ).

Statistical analysis was performed using IBM SPSS software for Windows (Version 20). Data was presented as mean and standard deviation (SD). The significance level was set at $\mathrm{P} \leq 0.05$. Kolmogorov-Smirnov and Shapiro-Wilk tests were used to assess data normality. All intergroup comparisons of Caspase- 3 area fraction at each time period were performed by One-Way ANOVA. Intragroup comparisons of Caspase-3 area fraction between both time periods were conducted using Independent Student t-test.
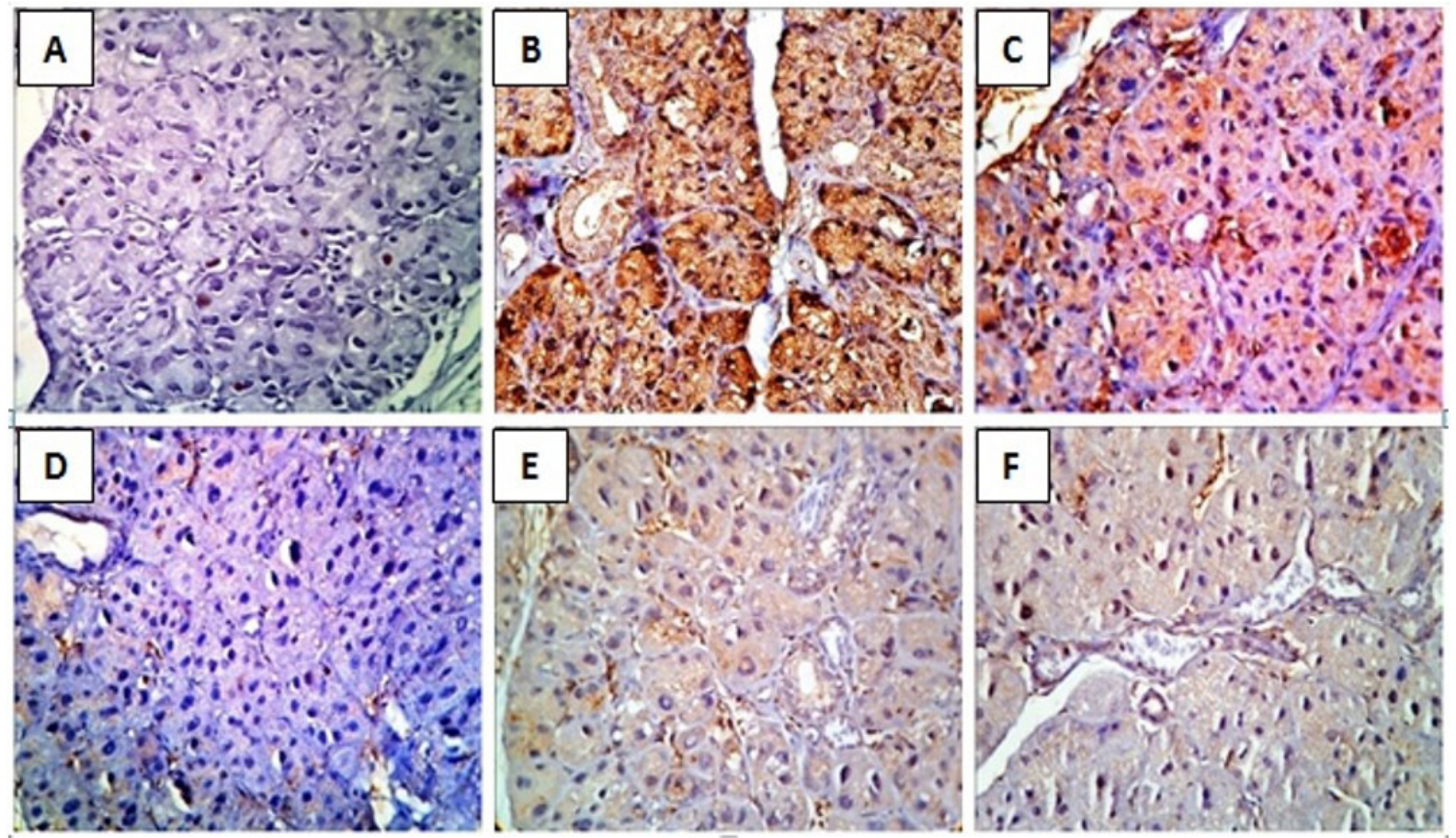

Figure 4 - (A) An immunostained photomicrograph of group 1 showing minimal positively stained acinar cells with caspase-3; (B) An immunostained photomicrograph of group 2 at day 6 , showing many areas of positive staining reaction to caspase-3 in both acinar and ductal cells; (C) An immunostained photomicrograph of group 3 at day 6 , showing apparent minimal areas of positive staining reaction to caspase-3 in acinar and ductal cells; (D) An immunostained photomicrograph of group 3 at day 10, showing minimal areas of positive staining reaction to caspase-3 in both acinar and ductal cells; (E) An immunostained photomicrograph of group 4 at day 6 showing wide areas of positive staining reaction to caspase-3 in both acinar and ductal cells; (F) An immunostained photomicrograph of group 4 at day 10 showing areas of positive staining reaction to caspase- 3 in both acinar and ductal cells (anti-caspase 3 orig. mag. X400). 

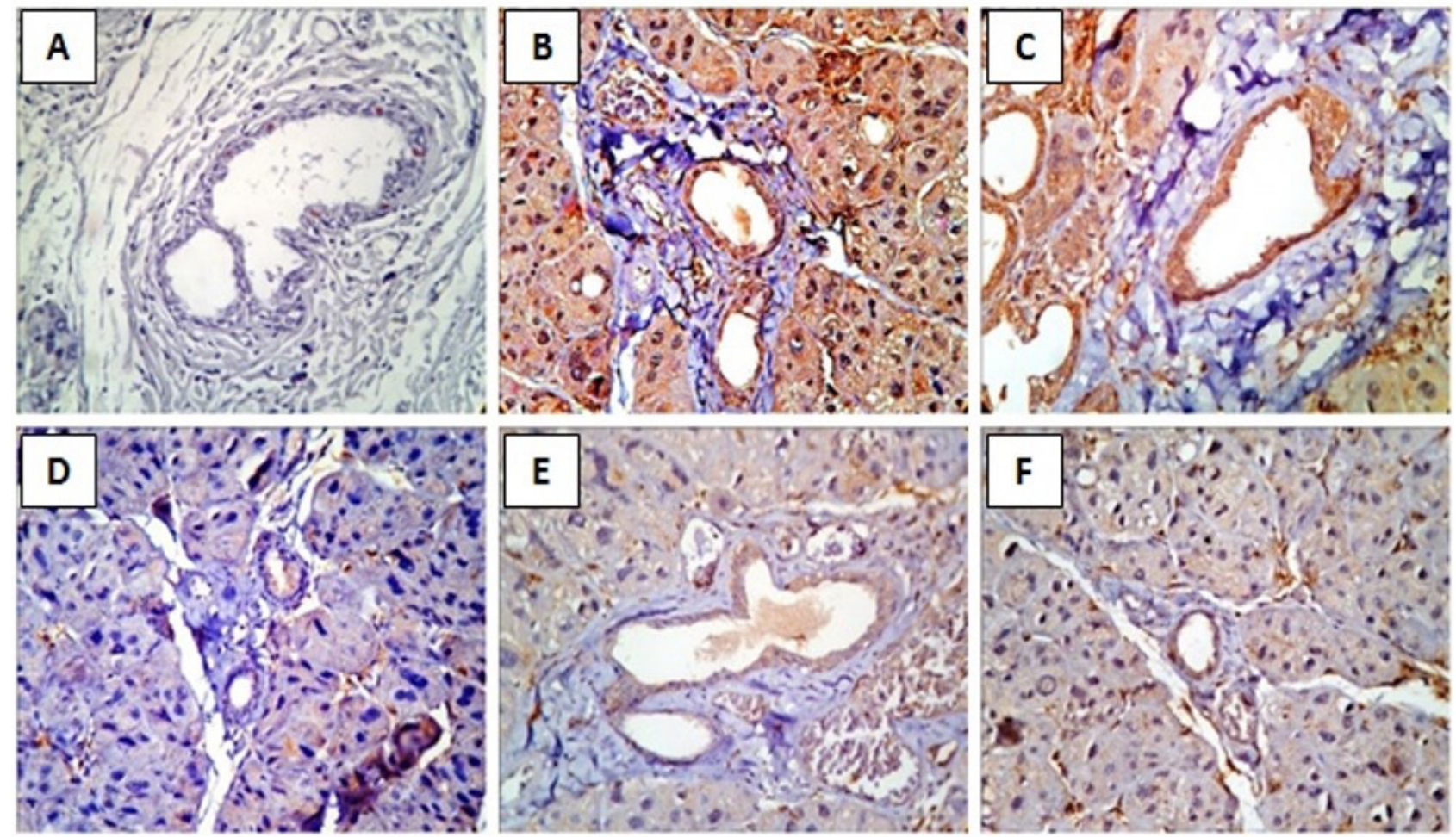

Figure 5 - (A) An immunostained photomicrograph of group 1 showing almost negatively stained ductal cells with caspase-3; (B) An immunostained photomicrograph of group 2 at day 10, showing many areas of positive staining reaction to caspase-3 in ductal and acinar cells; (C) An immunostained photomicrograph of group 3 at day 6, showing areas of positive staining reaction to caspase-3 in ductal cells; (D) An immunostained photomicrograph of group 3 at day 10, showing minimal areas of positive staining reaction to caspase-3 in both acinar and ductal cells; (E) An immunostained photomicrograph of group 4 at day 6 showing many areas of positive staining reaction to caspase- 3 in both acinar and ductal cells; (F) An immunostained photomicrograph of group 4 at day 10 showing areas of positive staining reaction to caspase-3 in both acinar and ductal cells (anti-caspase 3 orig. mag. X400).

Table I - Mean \pm SD and P-value for the effect of study groups on acinar area fraction percentage at each time period

\begin{tabular}{lccc} 
& 6 days & 10 days & P-value \\
\hline Negative control group & $72.80 \pm 8.11^{\mathrm{a}}$ & $75.92 \pm 1.38^{\mathrm{a}}$ & $0.547 \mathrm{NS}$ \\
\hline Positive control group & $45.06 \pm 5.85^{\mathrm{b}}$ & $48.94 \pm 8.69^{\mathrm{b}}$ & $0.556 \mathrm{NS}$ \\
\hline Local transplantation group & $61.22 \pm 6.68^{\mathrm{ab}}$ & $64.16 \pm 6.57^{\mathrm{ab}}$ & $0.616 \mathrm{NS}$ \\
\hline Systemic administration group & $64.01 \pm 4.14^{\mathrm{a}}$ & $69.57 \pm 6.51^{\mathrm{a}}$ & $0.280 \mathrm{NS}$ \\
\hline P-value & $0.004^{\star}$ & $0.005^{\star}$ &
\end{tabular}

Mean with different superscript letters within each column are statistically significant different at $\mathrm{P}<0.05$.

\section{Caspase-3 area fraction:}

One Way ANOVA (Table II) showed that there was a statistically significant difference in mean Caspase- 3 area fraction between study groups after 6 days $(\mathrm{P}<0.001)$ and 10 days $(\mathrm{P}<0.001)$. After 6 days, groups 2 and 4 displayed the significantly higher mean area fraction compared to group1 $(\mathrm{P}<0.05)$. While group 3 did not differ significantly from that of groups 1 and $4(\mathrm{P}>0.05)$. After 10 days, group 2 displayed the significantly highest mean area fraction $(\mathrm{P}<0.05)$; followed by group 4 . Results of group 3 showed statistically significant improvement compared to group 2 (positive control), however, as compared to group 4 , the differences were statistically non significant.
Independent Student t-test (Table II) showed that there was no statistically significant difference in mean Caspase-3 area fraction between both time periods within each study group $(\mathrm{P}=0.911$ in negative control group, $\mathrm{P}=0.449$ in positive control group, $\mathrm{P}=0.629$ in local transplantation group and $\mathrm{P}=0.252$ in systemic administration group).

\section{DISCUSSION}

The present study was conducted to shed a light on the most profound and effective method of administration of BMSCs by investigating possible regenerative effect of its systemic and local injection besides evaluating the effect of 5-FU on PGs of albino rats. 
Table II - Mean \pm SD and P-value for the effect of study groups on Caspase-3area fraction percentage at each time period

\begin{tabular}{lccc} 
& 6 days & 10 days & P-value \\
\hline Negative control group & $0.60 \pm 0.45^{c}$ & $0.55 \pm 0.48^{c}$ & $0.911 \mathrm{NS}$ \\
\hline Positive control group & $45.95 \pm 11.17^{\mathrm{a}}$ & $41.11 \pm 7.78^{\mathrm{a}}$ & $0.449 \mathrm{NS}$ \\
\hline Local transplantation group & $20.57 \pm 9.25^{\mathrm{bc}}$ & $17.94 \pm 7.23^{\mathrm{bc}}$ & $0.629 \mathrm{NS}$ \\
Systemic administration group & $31.76 \pm 11.72^{\mathrm{ab}}$ & $22.62 \pm 11.69^{\mathrm{b}}$ & $0.252 \mathrm{NS}$ \\
P-value & $<0.001^{*}$ & $<0.001^{*}$
\end{tabular}

*Significant at $\mathrm{P} \leq 0.05$. NS = not significant at $\mathrm{P}>0.05$. Mean with different superscript letters within each column are statistically significant different at $\mathrm{P}<0.05$.

5-Flourouracil is the most often used chemotherapy agent in the clinical oncology practice. It is widely used for managing various malignancies, including breast tumors, gastrointestinal cancer, and head and neck cancer [17]. And in recent years, it was administrated as the only standard cytostatic drug in the treatment of colorectal carcinoma [18]. The PG is the most significant SG in terms of the amount of saliva it produces during stimulated salivary flow, reaching more than half of the total volume of salivary secretions [19].

Bone marrow mesenchymal stem cells have been the most known and commonly utilized in medical practice since they were the first identified. Their great capacity for multiplication, potency to differentiate into specialized cells and constituents of specialized tissues and with immunomodulatory competence use, has made them the golden standard MSCs [20].

Evaluating systemic and local routes of administration is of critical importance in managing any disease. In SG disorders, a systemic delivery may affect the survival of acinar cells by providing cytoprotection to endothelial cells. However, a local delivery can provide higher levels of therapeutic agent besides reducing any systemic negative side-effects of the therapeutic drug. Hence it is important to evaluate and compare between both routes of injection [21].

Results of group 2 (the positive control group) after 5-FU administration showed illdefined acinar outline, multiple differentsized vacuolizations and disfigured nuclear pattern. These changes were more obvious 10 days after 5-FU administration. These findings were in accordance with previous studies that demonstrated that chemotherapeutic agents such as, 5-FU and Cisplatin, could induce SG acinar degeneration in the form of acinar and ductal cell vacuolization, nuclear pyknosis and subsequent apoptosis of the cells [16,22-24].
Typical characteristic morphological features for apoptosis as cell shrinkage, DNA fragmentation and chromatin condensation were clearly detected in group 2 which obviously denotes signs of degeneration or a pre-apoptotic phase of acinar and ductal cells [25]. These changes might be related to the mode of action of 5-FU which blocks the action of Thymidylate Synthase (TS), leading to Thiamine Monophosphate (TMP) deficiency which is a precursor one of the four deoxyribonucleotides required for DNA synthesis. This affects the nucleus leading DNA inhibition and cytotoxic alterations that lead to cell degeneration, desquamation and hyalinization [26]. It can be also be related to the fact that chemotherapeutic drugs can induce reactive oxygen species production leading to increased lipid peroxidation and calcium ions influx which also mediates apoptosis [9]. The epithelial atrophy in the acinar and ductal cells detected in group 2 of our study, obviously observed in the ED lining cells, could also be related to the impaired capacity of cell renewal due to the inhibitory effect of 5-FU on DNA replication and cell mitosis [27].

The intracytoplasmic vacuoles observed in group 2 in this study may be attributed to the damage of some intracellular structures which can fuse forming intracytoplasmic vacuoles [22].

Moreover, the pleomorphic nuclei including crescent-shaped nuclei that was detected in group 2 was related to be the fact that heterochromatin was separated from the euchromatin, resulting in the crescent form appearance. This noticeable signet ring shape was originally used to describe cells that exhibit peripheral displacement of the nucleus, due to cytoplasmic vacuolization related to hydropic degeneration displacing the nuclei from its original position [28]. Another explanation suggested that this shape was due to dense areas of chromatin condensation which 
is a histopathological characteristic feature of apoptotic cells [29].

Spacing between the acini and the surrounding ducts was also detected in group 2 which came in accordance with Bomfin et al. [2], who investigated the effect of 5-FU on SGs of rats. They explained these findings by the ability of 5-FU to induce periductal edema, reported in previous studies.

Stagnated secretion was also one of the results observed in the ductal lumen of group 2 specimens of our study. This could be related to the induced mitochondrial oxidative cytotoxicity induced by administration of 5-FU which reduces the ductal cells activity leading to this stagnation [30].

Homogeneous hyalinized areas in fibrous CT surrounding EDs also seen in group 2 in the present study, also in accordance with Hany et el [9]. and McInnes [30], were described as hyaline degeneration. Later they were indicated to be as accumulation of proteinaceous material in the tissues [31].

Cellular infiltration, vascular dilatation, and leukocyte margination were also observed in group 2 of this study, which were similar to previous results observed in oral mucosa biopsies of rats treated with 5-FU as early as $24 \mathrm{~h}$ after drug administration. This could be related to the oxidative stresses induced by 5-FU, which is associated with release of proinflammatory cytokines in major SGs as explained by Mafra et al. [32].

In the current study, the CT surrounding the ducts also showed signs of degeneration in group 2 with inflammatory cell infiltration, which comes in agreement with previous studies demonstrating the effect of 5-FU on collagen synthesis. It was evidenced that there is a selective, dose-dependent, and specific downregulation of collagen synthesis by fibroblasts in response to 5-FU [33].

Immunohistological results of group 2 of our study showed a wide area of positively stained acinar and ductal cells, both nuclear and cytoplasmic anti-caspase 3 reactions. These results came in accordance with Flanagan et al. [34] and Zahawi et al. [35], who reported that administration of 5-FU was accompanied with a significant increase in caspase- 3 expression. In another study, increasing the expression of caspases-3 and 7 was remarkable in 5-FU-treated colon cancer cells compared to the control group. They indicated that 5-FU significantly induced apoptosis and decreased surviving when compared with the control group.

These results may be explained by a previous study that stated that a higher number of inflammatory cells and the inflammatory cytokines as tumor necrosis factor alpha (TNF- $\alpha$ ), which lead to apoptotic cell death in SG cells have been evidenced following 5-FU administration [36].

In the current study, statistical analysis for the acinar area fraction of group 2 revealed that there was a decrease in the acinar size, which was more apparent at day 10 over day 6 . This could be related to the inflammation in the SGs and decrease of functional cells which cause the SG atrophy and reduction in acinar area fraction [2].

Results of group 3 of our study (the locally administered BMSCs into the 5-FU treated PGs group) showed acini with a more defined appearance, minimal cytoplasmic vacuolations, less hyperchromatic and pleomorphic nuclei. These findings coincide with the results of previous investigations on the effect of IG BMSCs transplantation into the SMGs of mice exposed to radiation that maintained acinar cell and gland morphologies along with superior gland functions as salivary flow rate and glandular weight $[37,38]$.

These results also came in agreement with Kawakami et al. [39] and Kim et al. [40], who investigated the effect of locally injected adiposederived mesenchymal stem cell (ADSCs) injection into damaged SGs of rats. They suggested that ADSCs transplantation might prevent atrophy of SG cells and act to regenerate acinar cells and restore saliva volume. They explained this by the fact that paracrine actions of the stem and progenitor cells are now known to promote wound healing, however the entirety of biomolecule production by various progenitor cell populations and their roles in wound healing have yet to be characterized.

The previous findings of the current study of group 3 were explained by proposed mechanisms by which BMSCs improve organ functions. Initial reports proposed the ability of BMSCs to (trans) differentiate into cells of a non marrow/nonhematopoietic lineage [41]. Then reports on fusion of BMSCs with cells of other tissues were documented [42]. The third proposed mechanism 
was vasculogenesis from endothelial progenitor cells contained within BM [43]. Lastly, the most recent mechanism is that BMSCs provide a local paracrine effect on endogenous cells that may be achieved by secreting anti-apoptotic, anti-inflammatory and proliferation promoting factors [44].

In the present study, minimal inflammatory cell infiltration, interacinar and periductal spacing were observed in group 3 at day 6 and day 10 . This could be attributed to fact that MSC-mediated modulations of the immune response sets in motion essential inflammatory processes that significantly promote tissue repair and regeneration [45].

Immunohistochemical results of group 3 in this study showed minimal caspase- 3 expression especially at day 10 . This was explained by Sumita et al. [10], who reported that histological analysis of irradiated SGs of mice treated with BMCs demonstrated an increased level of tissue regenerative activity, while apoptotic activity was increased in non-transplanted mice. These results also came in agreement Morsy et al. [46], who investigated the effect of local transplantation of SG-derived stem cells on the damaged SGs due to irradiation. They noted an apoptotic activity that was seen to decrease with time, peaking at 3 days after transplantation, and then declined at 1 week after transplantation.

In the current study, results of group 4 (the systemically administered BMSCs into the 5-FU treated PGs group) showed an overall improved histological picture that was more apparant at day 10. Acini and ducts had a more regular outline with minimal cytoplasmic cell vacuolations. These findings were consistent with Sumita et al. [10] and Tran et al. [47] who injected BMSCs in tail veins of rats with irradiated SMGs. These studies detected better SMG functions, increased proliferation, decreased apoptosis and increased vascularity as well. The authors justified their results by detecting elevated levels of interleukin 10 (IL-10) in the IV group where they suggested that the presence of BMSCs in the venous blood stimulates IL-10 release which can modulate the host immune response and enhances the healing process $[48,49]$.

Through analyzing the histological as well as the anti-caspase 3 immunohistochemical results of group 4 in this study, minimal histopathological as well as apoptotic changes were observed, especially at day 10 . This could be explained by the fact that BMSCs are able to inhibit the immune system, promote cell survival, induce angiogenesis or secrete a variety of mediators of tissue repair, including anti-apoptotic, antiinflammatory, immunomodulatory, anti-fibrotic and angiogenic agents $[50,51]$.

Regarding the comparison between the results of group 3 (local transplantation) and group 4 (systemic administration of BMSCs) in our study, both experimental groups showed apparent amelioration in the histological picture and decrease in caspase 3 expression, with progression of the experimental time periods. However, the statistical analysis of both the acinar area fraction as well as anticaspase 3 area fraction showed insignificant statistical difference between both modes of administration. In light of these findings, it might be wise considering the local mode of administration over the systemic route to avoid possible adverse-effects of MSCs such as an increased recurrence rate of cancer, particularly haematological malignancies [52,53].

\section{Acknowledgments}

This paper and the research behind it would not have been possible without the love of my family and the support of my mentor Prof. Dr. Medhat El Zainy. It is an honour working with a legend in this field like him. My deepest gratitude also goes to my supervisors Prof. Dr. Reham Magdy and Dr. Iman Fathy. Their knowledge and attention to detail have been my inspiration throughout this research.

We would also like to thank the anonymous reviewers of this paper for their valuable insights and appreciated comments.

\section{Conflict of Interest}

The authors declare no conflict of interest.

\section{Funding}

This study received no external funding

\section{Regulatory Statement}

The authors and co-authors have certified that all animal involving procedures were reviewed and approved by institution guidelines of Ain Shams University Ethical Committee with authorization number (FDASU - Rec IM031905). 


\section{REFERENCES}

1. Gupta N, Gupta R, Acharya AK, Patthi B, Goud V, Reddy S, et al. Changing trends in oral cancer-a global scenario. Nepal J Epidemiol. 2016;6(4):613-9. http://dx.doi.org/10.3126/nje. v6i4.17255. PMid:28804673.

2. Bomfin LE, Braga CM, Oliveira TA, Martins CS, Foschetti DA, Santos AA, et al. 5-Fluorouracil induces inflammation and oxidative stress in the major salivary glands affecting salivary flow and saliva composition. Biochem Pharmacol. 2017:145:34-45. http://dx.doi.org/10.1016/j.bcp.2017.08.024. PMid:28867645.

3. Fischer J, Ganellin CR. Analogue-based drug discovery. Weinheim: Wiley-VCH; 2006. Table of selected analogue classes.

4. Airley R. Cancer chemotherapy: basic science to the clinic Hoboken: John Wiley \& Sons; 2009.

5. Moore AY. Clinical applications for topical 5-fluorouracil in the treatment of dermatological disorders. J Dermatolog Treat. 2009;20(6):328-35. http://dx.doi. org/10.3109/09546630902789326. PMid:19954388

6. Boland PM, Hochster HS. Making fluorouracil "sexy" again. J Natl Cancer Inst. 2021;113(4):351-2. http://dx.doi.org/10.1093/jnci/ djaa125. PMid:32835362.

7. Yen MH, Wu YY, Liu YS, Rimando M, Ho JH, Lee OK. Efficient generation of hepatic cells from mesenchymal stromal cells by an innovative bio-microfluidic cell culture device. Stem Cell Res Ther. 2016;7(1):120. http://dx.doi.org/10.1186/s13287-016-03717. PMid:27542358.

8. Cheng MR, Li Q, Wan T, He B, Han J, Chen HX, et al. Galactosylated chitosan/5-fluorouracil nanoparticles inhibit mouse hepatic cancer growth and its side effects. World J Gastroenterol. 2012;18(42):6076-87. http://dx.doi.org/10.3748/ wjg.v18.i42.6076. PMid:23155336.

9. Hany E, Sobh MA, Abou ElKhier MT, EISabaa HM, Zaher AR. The effect of different routes of injection of bone marrow mesenchymal stem cells on parotid glands of rats receiving cisplatin: a comparative study. Int J Stem Cells. 2017;10(2):16978. http://dx.doi.org/10.15283/ijsc17022. PMid:28844126.

10. Sumita Y, Liu Y, Khalili S, Maria OM, Xia D, Key S, et al. Bone marrow-derived cells rescue salivary gland function in mice with head and neck irradiation. Int J Biochem Cell Biol. 2011;43(1):80-7. http://dx.doi.org/10.1016/j.biocel.2010.09.023. PMid:20933096.

11. Lotfy A, Salama M, Zahran F, Jones E, Badawy A, Sobh M. Characterization of mesenchymal stem cells derived from rat bone marrow and adipose tissue: a comparative study. Int J Stem Cells. 2014;7(2):135-42. http://dx.doi.org/10.15283/ ijsc.2014.7.2.135. PMid:25473451

12. Mazzeo MA, Linares JA, López MM, Gallará RV, Bachmeier E, Wietz FM, et al. Functional impairment in submandibular gland of rats induced by 5 -fluorouracil and calcium leucovorin. Acta Odontol Latinoam. 2012;25(3):262-8. PMid:23798072.

13. Jeong J, Baek H, Kim YJ, Choi Y, Lee H, Lee E, et al. Human salivary gland stem cells ameliorate hyposalivation of radiationdamaged rat salivary glands. Exp Mol Med. 2013;45(11):e58-58. http://dx.doi.org/10.1038/emm.2013.121. PMid:24232257.

14. Huang S, Xu L, Zhang Y, Sun Y, Li G. Systemic and local administration of allogeneic bone marrow-derived mesenchymal stem cells promotes fracture healing in rats. Cell Transplant. 2015;24(12):2643-55. http://dx.doi. org/10.3727/096368915X687219. PMid:25647659.

15. Bancroft J, Layton C. The hematoxylin and eosin In: Suvarna $\mathrm{S}$, editor. Theory practice of histological techniques. 7th ed. Philadelphia: Churchill Livingstone; 2013. http://dx.doi. org/10.1016/B978-0-7020-4226-3.00010-X.

16. Elgamily MF, Denewar M. Potential benefit of Annona muricata extract in combating cisplatin induced injury of parotid gland in albino rats. Egypt Dent J. 2020;66(2):997-1007. http://dx.doi. org/10.21608/edj.2020.23992.1027

17. Fakih MG. Metastatic colorectal cancer: current state and future directions. J Clin Oncol. 2015;33(16):1809-24. http://dx.doi. org/10.1200/JCO.2014.59.7633. PMid:25918280.

18. Bachmeier E, López MM, Linares JA, Brunotto MN, Mazzeo MA. 5-Fluorouracil and Cyclophosphamide modify functional activity in submandibular gland of rats. Journal of Oral Research. 2019;8(5):363-9.

19. Estafanos R. Extemporaneously compounded buccal pilocarpine preparations, acceptability and pilot testing for the treatment of xerostomia (dry mouth) in Australia [PhD thesis]. St. Lucia: The University of Queensland; 2020.

20. Escacena N, Quesada-Hernandez E, Capilla-Gonzalez V, Soria $B$, Hmadcha A. Bottlenecks in the efficient use of advanced therapy medicinal products based on mesenchymal stromal cells. Stem Cells Int. 2015;2015:895714. http://dx.doi. org/10.1155/2015/895714. PMid:26273307.

21. Xu J, Yan X, Gao R, Mao L, Cotrim AP, Zheng C, et al. Effect of irradiation on microvascular endothelial cells of parotid glands in the miniature pig. Int $J$ Radiat Oncol Biol Phys. 2010;78(3):897-903. http://dx.doi.org/10.1016/j. ijrobp.2010.05.048. PMid:20832188

22. Kitashima S. Morphological alterations of submandibular glands caused by cisplatin in the rat. Kurume Med J. 2005;52(1-2):29-38. http://dx.doi.org/10.2739/kurumemedj.52.29. PMid:16119610.

23. Özel O, Ayçiçek A, Kenar F, Aktepe F, Sargin R, Yilmaz MD, et al. Histopathologic changes in the rabbit submandibular gland after 5-fluorouracil chemotherapy. Turk J Med Sci. 2010;40(2):213-20.

24. Hitomi S, Ujihara I, Sago-Ito M, Nodai T, Shikayama T, Inenaga $K$, et al. Hyposalivation due to chemotherapy exacerbates oral ulcerative mucositis and delays its healing. Arch Oral Biol. 2019;105:20-6. http://dx.doi.org/10.1016/j. archoralbio.2019.06.003. PMid:31238198.

25. Lee JE, Nakagawa T, Kita T, Kim TS, Iguchi F, Endo T, et al. Mechanisms of apoptosis induced by cisplatin in marginal cells in mouse stria vascularis. ORL J Otorhinolaryngol Relat Spec. 2004;66(3):111-8. http://dx.doi.org/10.1159/000079329. PMid:15316230.

26. Wlodkowic D, Telford W, Skommer J, Darzynkiewicz Z. Apoptosis and beyond: cytometry in studies of programmed cell death. Methods Cell Biol. 2011;103:55-98. http://dx.doi.org/10.1016/ B978-0-12-385493-3.00004-8. PMid:21722800.

27. Elmansy MN, Hegazy EM. Evaluation of the Apoptotic changes induced by 5-Fluorouracil on the Lingual Mucosa and Salivary glands of male albino rats (Histological, Histomorphometric and Immunohistochemical Study). Egypt Dent J. 2020;66(4):2353-63. http://dx.doi.org/10.21608/edj.2020.41503.1240

28. Kim DY, Cho SB, Chung KY, Kim YC. Clear cell basal cell carcinoma with sialomucin deposition. Yonsei Med J. 2006:47(6):870-2. http://dx.doi.org/10.3349/ymj.2006.47.6.870. PMid:17191318.

29. El-Direny EA, Shalaby NM, Afif OK. Effect of irradiation on secretory cells of submandibular gland of adult male albino rat. Histological and immunohistochemical study. Egypt J Histol. 2009;32(2):324-32

30. Deveci HA, Nazıroğlu M, Nur G. 5-Fluorouracil-induced mitochondrial oxidative cytotoxicity and apoptosis are increased in MCF-7 human breast cancer cells by TRPV1 channel activation but not Hypericum perforatum treatment. Mol Cell Biochem. 2018;439(1-2):189-98. http://dx.doi.org/10.1007/s11010-0173147-1. PMid:28795251.

31. Mclnnes EF. Background lesions in laboratory animals: a color atlas. London: Elsevier; 2012. Wistar and sprague-dawley rats; p. 17-36. 
32. Mafra CADCC, Vasconcelos RC, Medeiros CACXD, Leitão RFDC, Brito GADC, Costa DVDS, et al. Gliclazide prevents 5-FU-induced oral mucositis by reducing oxidative stress, inflammation, and P-selectin adhesion molecules. Front Physiol. 2019;10:327. http:// dx.doi.org/10.3389/fphys.2019.00327. PMid:30971955.

33. Bulstrode NW, Mudera V, McGrouther DA, Grobbelaar AO, Cambrey AD. 5-fluorouracil selectively inhibits collagen synthesis. Plast Reconstr Surg. 2005;116(1):209-21. http://dx.doi. org/10.1097/01.PRS.0000169701.16509.D6. PMid:15988270.

34. Flanagan L, Meyer M, Fay J, Curry S, Bacon O, Duessmann $\mathrm{H}$, et al. Low levels of Caspase-3 predict favourable response to 5FU-based chemotherapy in advanced colorectal cancer: Caspase-3 inhibition as a therapeutic approach. Cell Death Dis. 2016;7(2):e2087-2087. http://dx.doi.org/10.1038/cddis.2016.7. PMid:26844701.

35. Zahawi SM, Al-Refai AS, Abdulqader HA. Evaluation of the effect of chamomile extract on lingual histological changes in rabbit received 5-fluorouracil (histological and immunohistochemical study). Zanco J Med Sci. 2017;21(1):1552-60. http://dx.doi. org/10.15218/zjms.2017.003.

36. Kamachi M, Kawakami A, Yamasaki S, Hida A, Nakashima T, Nakamura $H$, et al. Regulation of apoptotic cell death by cytokines in a human salivary gland cell line: distinct and synergistic mechanisms in apoptosis induced by tumor necrosis factor alpha and interferon gamma. J Lab Clin Med. 2002;139(1):13-9. http://dx.doi.org/10.1067/mlc.2002.120648. PMid:11873240

37. Lin CY, Chang FH, Chen CY, Huang CY, Hu FC, Huang WK, et al. Cell therapy for salivary gland regeneration. J Dent Res. 2011;90(3):3416. http://dx.doi.org/10.1177/0022034510386374. PMid:21297017.

38. Lim JY, Yi T, Choi JS, Jang YH, Lee S, Kim HJ, et al. Intraglandular transplantation of bone marrow-derived clonal mesenchymal stem cells for amelioration of post-irradiation salivary gland damage. Oral Oncol. 2013;49(2):136-43. http://dx.doi. org/10.1016/j.oraloncology.2012.08.010. PMid:22981389.

39. Kawakami M, Ishikawa H, Tanaka A, Mataga I. Induction and differentiation of adipose-derived stem cells from human buccal fat pads into salivary gland cells. Hum Cell. 2016;29(3):101-10. http://dx.doi.org/10.1007/s13577-016-0132-z. PMid:26842556.

40. Kim JW, Kim JM, Choi ME, Kim SK, Kim YM, Choi JS. Adiposederived mesenchymal stem cells regenerate radioiodineinduced salivary gland damage in a murine model. Sci Rep. 2019;9(1):15752. http://dx.doi.org/10.1038/s41598-019-517759. PMid:31673085.

41. Grove JE, Bruscia E, Krause DS. Plasticity of bone marrow-derived stem cells. Stem Cells. 2004;22(4):487-500. http://dx.doi. org/10.1634/stemcells.22-4-487. PMid:15277695.

42. Quintana-Bustamante $O$, Alvarez-Barrientos $A$, Kofman AV, Fabregat I, Bueren JA, Theise ND, et al. Hematopoietic mobilization in mice increases the presence of bone marrow- derived hepatocytes via in vivo cell fusion. Hepatology. 2006;43(1):108-16. http://dx.doi.org/10.1002/hep.21005. PMid:16374873.

43. Ding YT, Kumar S, Yu DC. The role of endothelial progenitor cells in tumour vasculogenesis. Pathobiology. 2008;75(5):265-73. http://dx.doi.org/10.1159/000151706. PMid:18931528.

44. Zarjou A, Kim J, Traylor AM, Sanders PW, Balla J, Agarwal $A$, et al. Paracrine effects of mesenchymal stem cells in cisplatininduced renal injury require heme oxygenase-1. Am J Physiol Renal Physiol. 2011;300(1):F254-62. http://dx.doi.org/10.1152/ ajprenal.00594.2010. PMid:21048024

45. Li Y, Zhang D, Xu L, Dong L, Zheng J, Lin Y, et al. Cell-cell contact with proinflammatory macrophages enhances the immunotherapeutic effect of mesenchymal stem cells in two abortion models. Cell Mol Immunol. 2019;16(12):908-20. http:// dx.doi.org/10.1038/s41423-019-0204-6. PMid:30778166.

46. Morsy RA, Abbas EA, Shalash HN, El-Hamid ES, Baghdadi HM, The effect of salivary gland-derived stem cell transplantation on the regeneration of gamma-irradiated rat submandibular salivary glands: an immunohistochemical study. J Arab Soc Med Res. 2019;14(2):62. http://dx.doi.org/10.4103/jasmr.jasmr_13_19.

47. Tran SD, Liu Y, Xia D, Maria OM, Khalili S, Wang RWJ, et al. Paracrine effects of bone marrow soup restore organ function, regeneration, and repair in salivary glands damaged by irradiation. PLoS One. 2013;8(4):e61632. http://dx.doi. org/10.1371/journal.pone.0061632. PMid:23637870

48. Guo W, Wang H, Zou S, Gu M, Watanabe M, Wei F, et al. Bone marrow stromal cells produce long-term pain relief in rat models of persistent pain. Stem Cells. 2011;29(8):1294-303. http:// dx.doi.org/10.1002/stem.667. PMid:21630378.

49. Zhao F, Qu Y, Liu H, Du B, Mu D. Umbilical cord blood mesenchymal stem cells co-modified by TERT and BDNF: A novel neuroprotective therapy for neonatal hypoxic-ischemic brain damage. Int J Dev Neurosci. 2014;38(1):147-54. http:// dx.doi.org/10.1016/j.ijdevneu.2014.06.014. PMid:24999119.

50. Abd El-Haleem MR, Selim AO, Attia GM. Bone marrowderived mesenchymal stem cells ameliorate parotid injury in ovariectomized rats. Cytotherapy. 2018;20(2):204-17. http:// dx.doi.org/10.1016/j.jcyt.2017.10.003. PMid:29254763.

51. Hmadcha A, Martin-Montalvo A, Gauthier BR, Soria B, CapillaGonzalez V. Therapeutic potential of mesenchymal stem cells for cancer therapy. Front Bioeng Biotechnol. 2020;8:43. http:// dx.doi.org/10.3389/fbioe.2020.00043. PMid:32117924.

52. Wong RS. Mesenchymal stem cells: angels or demons? J Biomed Biotechnol. 2011;2011:459510. http://dx.doi. org/10.1155/2011/459510. PMid:21822372.

53. Musiał-Wysocka A, Kot M, Majka M. The pros and cons of mesenchymal stem cell-based therapies. Cell Transplant. 2019;28(7):801-12. http://dx.doi. org/10.1177/0963689719837897. PMid:31018669.

\section{Caroline Maged Massieh} (Corresponding address) The British University in Egypt, Faculty of Dentistry, Department of Oral Biology, Suez Desert Road El Sherouk City, 11837, Cairo, Egypt. Email: caroline.maged@bue.edu.eg

Date submitted: 2021 June 14 Accept submission: 2021 Aug 04 